\title{
Sulphasalazine induced hepatitis in juvenile rheumatoid arthritis
}

\author{
D Caspi, D Fuchs, $M$ Yaron
}

\begin{abstract}
Two 19 year old patients with juvenile chronic arthritis developed liver toxicity during treatment with sulphasalazine. A significant increase in the levels of liver enzymes in serum samples was noticed in relation to the initiation of treatment in one patient and to the increase in dose in the second. The enzymes returned to normal levels 14 days after the drug had been stopped. A rechallenge in one of the patients caused re-exacerbation. This is the first report of liver toxicity induced by sulphasalazine in juvenile chronic arthritis. As spontaneous liver involvement in juvenile chronic arthritis is not rare, the possibility of drug induced hepatitis should be recognised in these patients.
\end{abstract}

Sulphasalazine, a drug used for many years in the treatment of inflammatory bowel disease, has played an increasingly important part in the treatment of rheumatic diseases. The drug has proved its efficacy in the treatment of adult rheumatoid arthritis ${ }^{1-3}$ and in other seronegative arthritides. ${ }^{45}$ Sulphasalazine is also effective in juvenile chronic arthritis. ${ }^{6-8}$

Hepatic toxicity to sulphasalazine is not common and was reported in $2.5 \%$ of 200 adult patients with rheumatoid arthritis. ${ }^{3}$ Until now, no hepatotoxicity has been reported in juvenile arthritis, ${ }^{9}$ although it has been described in the treatment of childhood inflammatory bowel disease. ${ }^{10} \mathrm{We}$ present here two young adult patients with juvenile chronic arthritis who developed hepatitis following treatment with sulphasalazine.

\section{Case reports}

CASE 1

A 13 year old girl had a systemic onset juvenile chronic arthritis, characterised by a prolonged spikey fever, evanescent rash, lymphadenopathy, splenomegaly, polyarthritis, leucocytosis and hyperglobulinaemia. Rheumatoid factor was negative but a positive low titre of antinuclear antibodies was present with normal antibodies to DNA. She developed chronic deforming arthritis, mainly in her wrists, proximal interphalangeal joints, and knees. At the age of 14, while receiving diclofenac, she had hepatitis with a marked increase of transaminase, alkaline phosphatase, and bilirubin concentrations. Serolgical tests for cytomegalovirus, Epstein-Barr virus, and hepatitis B virus were negative. A needle biopsy of the liver suggested toxic hepatitis. The drug was stopped and liver tests returned to normal values.
At the age of 19 years, treatment with sulphasalazine EN was started due to a persistently active arthritis. Three weeks later, while receiving $1.5 \mathrm{~g}$ per day sulphasalazine, she developed chills, high fever, headache, vomiting, and a mild erythematous rash on her arms and chest. On physical examination she was febrile without jaundice, the liver was mildly enlarged without tenderness, and her spleen was palpable within its usual size of three centimetres below the costal margin.

Laboratory tests showed increased levels of transaminase and alkaline phosphatase (table). Serological tests for cytomegalovirus, EpsteinBarr virus, and hepatitis B virus were negative. Sulphasalazine was stopped and the liver enzymes in serum samples returned to normal levels within two weeks. At that stage a rechallenge with a single $0.5 \mathrm{~g}$ dose of sulphasalazine produced chills, vomiting, fever and general malaise within 24 hours. Prednisone $(15 \mathrm{mg}$ ) was given with a marked improvement within four days. Prednisone was stopped after one week.

\section{CASE 2}

This 19 year old woman has been followed up by our department since the age of three years when she was found to have pauciarticular juvenile chronic arthritis with recurrent uveitis, antinuclear antibodies, and negative antibodies to DNA. The course of her disease was characterised by spontaneous remissions and exacerbations until the age of 15 years when a gradual increase in the number of joints affected was noticed. Symmetrical synovitis affecting the temporal bone and mandible, wrists, knees, and ankles developed. Rheumatoid factor remained negative:, She responded partially to nonsteroidal anti-inflammatory drugs (NSAIDs) but two years later an exacerbation occurred.

While receiving ibuprofen $(200 \mathrm{mg}$ three times a day), which had been given for the previous three months, sulphasalazine was prescribed with gradual weekly increments of the dose. The patient failed to follow the instructions and continued a low dose of $0.5 \mathrm{mg}$ twice daily for the next three months, which she spent abroad. On returning to this hospital the dose was increased by a further $0.5 \mathrm{~g}$ a day each week and routine liver laboratory tests were repeated. Within a few days general malaise, upper abdominal pain and nausea were noticed. The patient, however, reported her symptoms only two weeks later, when already receiving $2 \mathrm{~g}$ a day of sulphasalazine. On physical examination she appeared to be generally well and afebrile
Tel Aviv,

Accepted for publication 2 April 1991 
Results of laboratory tests of two patients with juvenile chronic arthritis with sulphasalazine induced hepatitis

\begin{tabular}{lll}
\hline Laboratory tests* & $\begin{array}{c}\text { Patient No 1 } \\
(2 \cdot 0 \mathrm{~g} \text { sulphasalazine })\end{array}$ & $\begin{array}{c}\text { Patient No 2 } \\
(1 \cdot 0 \mathrm{~g} \text { sulphasalazine })\end{array}$ \\
\hline Total bilirubin $(<17 \mu \mathrm{mol} / \mathrm{l})$ & $13 \cdot 7$ & $30 \cdot 8$ \\
Alkaline phosphatase $(30-85 \mathrm{mU} / \mathrm{ml})$ & 212 & 249 \\
Aspartate aminotransferase $(7-40 \mathrm{mU} / \mathrm{ml})$ & 180 & 900 \\
Alanine aminotransferase $(<22 \mathrm{mU} / \mathrm{ml})$ & 69 & 520 \\
Lactate dehydrogenase $(160-320 \mathrm{mU} / \mathrm{ml})$ & $\mathrm{ND}$ & 492 \\
Cytomegalovirus & Negative & Negative \\
Hepatitis B surface antigen & Negative & Negative \\
Hepatitis B core antigen & Negative & Negative \\
Hepatitis A virus & Negative & Negative \\
\hline
\end{tabular}

*Normal values and units given in parentheses.

$\mathrm{ND}=$ not determined. reported two patients with a reversible increase of liver enzymes ${ }^{12}$ and an overall $2 \cdot 5 \%$ rate of liver toxicity in 200 adult patients with rheumatoid arthritis receiving sulphasalazine. ${ }^{3}$ In an overview of 774 patients from Birmingham, Glasgow and Sheffield, Amos et al concluded that liver toxicity is rare, leading to withdrawal from sulphasalazine in only $0.3 \%$ of patients. ${ }^{1}$

The use of sulphasalazine in the treatment of juvenile chronic arthritis was first described by Ozdogan et al. ${ }^{6}$ Since then a few reports on the use of sulphasalazine in treating children with juvenile chronic arthritis have been published, ${ }^{6-10}$ encompassing several dozen patients, none of whom had liver toxicity.

The present report is the first on transient liver damage as a result of treatment with sulphasalazine in juvenile chronic arthritis. Involvement of the liver as part of systemic onset juvenile chronic arthritis is not rare. ${ }^{13}$ Drugs, notoriously aspirin and some other NSAIDs may also give rise to liver damage. ${ }^{14} \mathrm{It}$ is thus of importance to recognise the possibility of sulphasalazine induced hepatitis in these patients.

1 Amos R S, Pullar T, Situnayake D, Capell H A, McConkey B Sulphasalazine for rheumatoid arthritis toxicity in 774 patients monitored for one to 11 years. $B M \mathcal{F} 1986 ; 293$. 419-23.

2 Pinals R S. Sulphasalazine in the rheumatic diseases. Semin Arthritis Rheum 1988; 17: 246-59.

3 Farr M, Bacon P A, Coppock J, Scott D L. Long term experience of Salzopyrin EN in rheumatoid arthritis. Scand experience of Salzopyrin EN in rhe

4 Mielants H, Veys E N, Joos R. Sulphasalazine (Salazopyrin) in the treatment of enterogenic reactive synovitis and ankylosing spondylitis with peripheral arthritis. Clin Rheumatol 1986; 5: 80-3.

5 Ghozlan R, Dupuis M, Schwak A, Jorro P, Lecarpentier Ch Guillon C. Traitement de la polyarthrite rheumadoide par la salazosulfapyridine. Rev R hum 1988; 55: 127-30

6 Ozdogan H, Trune M, Deringol B, Yardakul S, Yazici H Sulphasalazine in the treatment of juvenile rheumatoid arthritis. A preliminary open trial. $\mathcal{F}$ Rheumatol $1986 ; 13$ $124-5$.

7 Grondin C, Malleson P, Petty R E. Slow acting anti-rheumatic drugs in chronic arthritis of childhood. Semin Arthritis Rheum 1988; 18: 38-47.

8 Suschke H J. Die therapie der juvenielen chronischen Arthritis mit Sulfasalazin. Z Rheumatol 1987; 46: 83-5.

9 Rosenberg A M. Advanced drug therapy for juvenile rheumatoid arthritis. $\mathcal{F}$ Pediatr 1989; 114: 171-8.

10 Boyer D L, Ulysses K L, Fyda J N, Friedman R A. Sulphasalazine induced hepatotoxicity in children with inflammatory bowel disease. 7 Pediatr Gastroenterol Nutr 1989; 8 : 528-32.

11 Berliner S, Neeman A, Schoenfeld Y. Salazopyrin induced eosinophilic pneumonia. Respiration 1980; 39: 119-20.

12 Farr M, Symmons D P, Bacon P A. Raised serum alkaline phosphatase and aspartate transaminase levels in two rheumatoid patients treated with sulphasalazine. Ann Rheum Dis 1985; 44: 498-500.

13 Schaller J G, Beckwith B, Wedgwood J R. Hepatic involvement in juvenile rheumatoid arthritis. $f$ Pediatr 1970; 77: 203.

A variety of other side effects has been reported. Instances of liver toxicity induced by sulphasalazine have been noted in adult patients with rheumatoid arthritis. Farr and co-workers 